Vietnam Journal of Earth Sciences 37 (2015) 289-298

Vietnam Academy of Science and Technology
Vietnam Journal of Earth Sciences
Website: http://www.vjs.ac.vn/index.php/jse

\title{
Paleomagnetism of upper permian basaltic rocks of Cam Thuy formation from Thuan Chau locality, Son La, Northwest Vietnam
}

Cung Thuong Chi ${ }^{1}$ John W. Geissman ${ }^{2}$, Hoang Van Quy ${ }^{1}$, Tran Viet Anh ${ }^{1}$, Nguyen Thi Phuong Dung ${ }^{1}$, Nguyen Thi Hoc ${ }^{1}$

${ }^{1}$ Institute of Geological Sciences, Vietnam Academy of Science and Technology

${ }^{2}$ Department of Geosciences, University of Texas at Dallas

Accepted 25 December 2015

\section{ABSTRACT}

Oriented-core samples (74) from eight sites collected from the Late Permian basaltic Cam Thuy formation exposed at Thuan Chau locality, Son La Province, northwestern Vietnam yield interpretable magnetizations in progressive demagnetization. The characteristic remanent magnetization (ChRM) components carried by magnetite and hematite are successfully isolated from secondary components reveal a mean, stratigraphic coordinates paleomagnetic direction of Ds $=216.1^{\circ}, \mathrm{Is}=10.5^{\circ}\left(\alpha_{95}=8.9^{\circ}, \mathrm{k}=\right.$ $107.8, \mathrm{~N}=7$ site mean directions), corresponding to a virtual geomagnetic pole located at $\lambda=45.6^{\circ} \mathrm{N}, \phi=226.8^{\circ} \mathrm{E}$ and a paleolatitude for the study area situated at $\pm 5.3^{\circ} \mathrm{N}$ during the Late Permian. A comparison of the pole we report in this study with the Late Permian pole of South China Block shows that this basaltic terrane of northwest Vietnam has been close to if not a coherent part of the South China Block since Late Permian. This result implies that insignificant cumulative displacement has occurred along the Ailao Shan/Red River fault system during the Cenozoic India-Eurasia collision.

C 2015 Vietnam Academy of Science and Technology

\section{Introduction}

The Permian was a particularly important period in the geological evolution of Southeast Asia, where involved successive dispersion and northwards translation of continental blocks during the opening and closing the Paleo-, Meso-, and Neo-Tethys oceans, and their amalgamation and accretion to form present-day SE Asia. In the Southeast Asian region, continental collisions and accretion occurred in two distinct phases, one in the Late Paleozoic-Early Mesozoic and one in the Late Mesozoic and Cenozoic (Metcalfe, 2013).

On the basis of biogeographic and paleomagnetic data, paleogeographic reconstruction

"Corresponding author, Email: chicung@gmail.com models of Permian eastern Pangea and Tethys have been proposed by different workers (Sengor, 1979, 1984, 1988, 1989; Hutchison, 1989; Gatinsky and Hutchison, 1986; Metcalfe, 1988, 1991, 1996, 2002, 2011; Scotese et al., 1992, 1995; Dercourt et al., 1993; Ziegler et al., 1997; Zonenshain et al., 1985; Li et al., 1993; Li and Powell, 2001). All of the reconstruction models broadly agree on the reconstruction of the principal components of Pangea.

Most models for the position of South China during the Permian have the sub-continent situated on, or slightly south of the equator and slightly counter-clockwise rotated; this configuration has been supported by paleomagnetic, biogeographic and climatic data and it did not experience 
Cung Thuong Chi, et al./Vietnam Journal of Earth Sciences 37 (2015)

significant latitudinal displacement during the Permian. The position of the Indochina Block, however, is somewhat in dispute. Scotese and McKerrow, 1990; Metcalfe 1998, 2002; Li and Powell, 2001)position Indochina and South China together, welded along the Song Ma Suture Zone during Late Devonian-Early Carboniferous and forming the South China- Indochina Super-terrane during the Permian, characterized by Tethyan fauna and Cathaysian flora (Ziegler et al., 1997, 1998), on the other hand, argue that these terranes remain separated during the Permian.

During the last twenty years, many paleomagnetic results from studies of Paleozoic to Mesozoic rock formations exposed in the South China block have been reported by different workers and these data enable the construction of an Apparent Polar Wander Path (APWP) for the South China Block and serve to define the approximate paleo-latitude and orientation of this block during the Permian. However, there are few paleomagnetic studies on Permian-Triassic rock formations from the Indochina Block, lying southwest of the South China Block (Achache and Courtillot, 1985; Chen and Courtillot, 1989; Yang and Besse, 1993), especially from the Vietnam region (Cung et al., 2000a).

In Vietnam, initial paleomagnetic work on these basalts was carried out by Cung, 1996, who collected in the Hoa Binh and Son La areas. Renewed sampling was carried out by the authors in northwest Vietnam in 2013 and efforts were concentrated on Upper Permian to Lower Triassic volcanic rock sequences that crop out from Hoa Binh to Lai Chau province near the border with the People's Republic of China. Independently oriented samples (as drilled cores) were collected from numerous localities, and these were and continue to be analyzed in the Paleomagnetism Laboratory at the University of Texas at Dallas, USA. In this paper, only the paleomagnetic results obtained from basaltic rocks at Thuan Chau locality are presented.

\section{Geologic - tectonic setting and sampling area}

The continental core of mainland Southeast Asia comprises the Sibumasu, Indochina and
South China blocks and the Sukhothai island Arc terrane, located between Sibumasu and South China/Indochina (Sone and Metcalfe, 2008; Metcalfe, 2012). The South China and Indochina blocks are considered to have already amalgamated along the Song Ma Suture Zone in Carboniferous and therefore formed a superterrane in the Permian which has been termed 'Cathaysialand' by some authors (Figure 1).

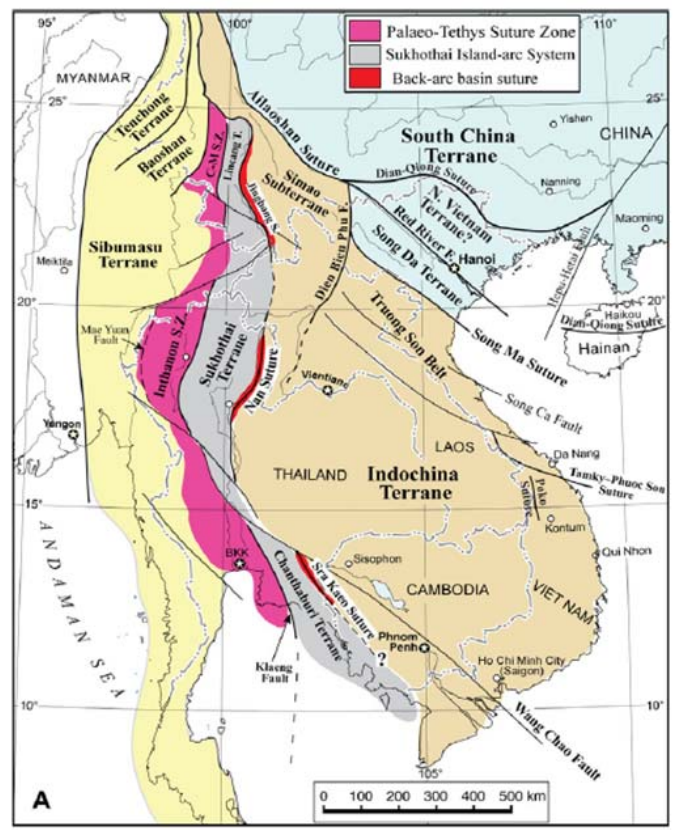

Fig. 1. Sketch map of major tectonic units of SE Asia (after Metcalf, 2012)

Upper Permian - Lower Triassic volcanic rocks are widely exposed in northwest Vietnam, mainly within the Song Da rift basin located NE of the Song Ma Suture Zone that forms the boundary between the South China Block and the Indochina Block. Permian basalts within the Song Da rift are considered distal equivalents of the Emeishan rift basalts; the geochemistry of these basalts and associated Permian-Triassic komatiites suggests a plume related source (Hanski et al., 2004; Zhou et al., 2008). On the other hand, Lepvrier et al., 2004, 2008) suggest that the Permian basalts exposed north of the Song Ma Suture Zone (within Song Da rift basin) could have been emplaced in a backarc continental setting due to a north-dipping oceanic subduction system of Indochina beneath 
Vietnam Journal of Earth Sciences 37 (2015) 289-298

South China, yet an inferred calc-alkaline magmatic arc of that age is not well documented. Some authors suggest that Indochina and South China were separated by oceanic crust in the Late Permian to Early-Middle Triassic and that they collided during the Indosinian Orogeny in the Late Triassic (Zhang et al., 2006; Zhang and Cai, 2009; Cai and Zhang, 2009).

Permian flood basalts and associated maficultramafic intrusions form a narrow NW-trending belt in the Song Da rift terrane. The belt is bounded by the Red River fault zone to the northeast and the Song Ma suture to the southwest (Fig. 2).

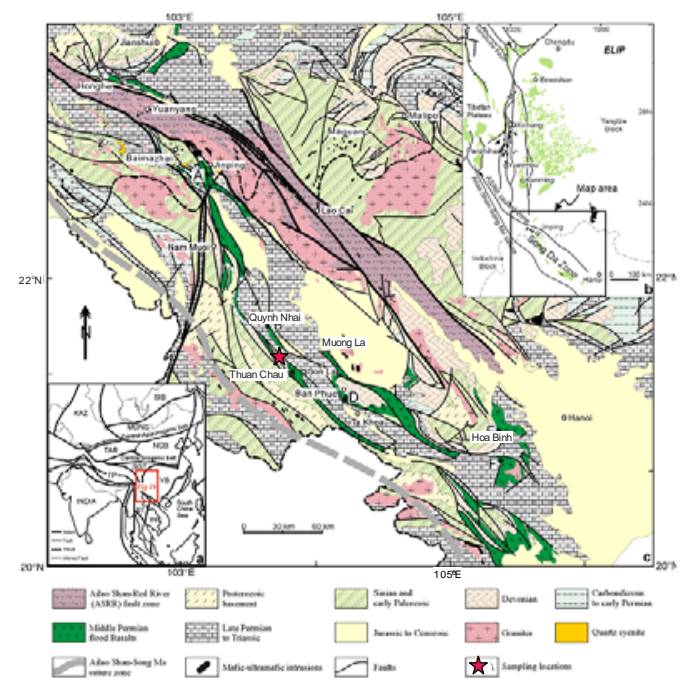

Fig. 2. Geological sketch map of the NW Vietnam region showing the study area, modified from Wang et al. (2007). The major blocks shown in inset (a) are: SIB, Siberia; MONG, Mongolia; NCB, North China Block; YB, Yangtze Block; INC, Indochina Block; TAR, Tarim; KAZ, Kazakhstan; TP, Tibet Plateau; SGT, Songpan-Ganze terrane. The Emeishan Large Igneous Province in SW China and northern Vietnam is shown in inset (b).

The flood basalts unconformably overlie the early Permian limestones, and are concordantly overlain by the early Triassic limestone and shale (Glotov et al., 2001). Folded Triassic sedimentary rocks are unconformably overlain by Cretaceous conglomerates, sandstones and pelites (Lacassin et al., 1998).

Upper Permian - Lower Triassic volcanic rocks in the Song Da rift terrane have been divided into the Cam Thuy and Vien Nam formations. The
Upper Permian Cam Thuy Formation (Dinh Minh Mong, 1978) consists of mafic extrusive rocks, of tholeiitic affinity that are widely exposed in the southeast part of the Song Ma anticline within Thanh Hoa, Ninh Binh, Hoa Binh, Son La and Lao Cai provinces. The volcanic rocks of Cam Thuy Formation are, in general, basalt, basaltic andesite, or andesite and are up to $1000 \mathrm{~m}$ thick (Hoa Binh area). They are dominated by high magnesium, low titanium and alkaline basalt, equivalent to tholeiite series rocks (Polyakov et al., 1991, 1999; Hoa et al., 2001, 2004, and 2008). Based on isotopic age determinations (Polyakov et al., 1999; Tran Trong Hoa, 1996; Hanski et al., 2004), the interpreted age of the basaltic rocks is about $257 \pm$ $24 \mathrm{Ma}$, corresponding to the Late Permian.

At Thuan Chau locality, eight sites with 74 core samples were collected on basaltic rocks of Cam Thuy Formation that crop out along the road from Son La city to Thuan Chau district.

\section{Paleomagnetism and rock magnetism}

Individual specimens of $25 \mathrm{~mm}$ in diameter and $22 \mathrm{~mm}$ in length were prepared from each sample in the laboratory. Natural remanent magnetizations (NRMs) were measured using a 2-G Enterprises three-axis, DC-SQUID pulse cooled cryogenic magnetometer. One specimen from each sample was subjected to stepwise thermal demagnetization up to $690^{\circ} \mathrm{C}$ using an ASC TDS-48 thermal demagnetizer with a residual field below $5 \mathrm{nT}$. Another specimen of the same sample was subjected to stepwise alternating field (AF) demagnetization up to $100 \mathrm{mT}$ in order to choose the most effective demagnetization method for the rest of samples. Demagnetization results for each specimen were plotted on orthogonal vector diagrams (Zijderveld, 1967) to assess component structure as well as on equal-area projections to evaluate directional consistency. Principal component analysis (Kirschvink, 1980) was used to estimate components directions. Site-mean directions were calculated using Fisherian statistics (Fisher, 1953). The natural remanent magnetizations of basaltic rocks are rather strong, ranging from $24.4 \mathrm{~mA} / \mathrm{m}$ to $4.45 \mathrm{~A} / \mathrm{m}$ and consist of two or more components (Fig. 3 to Fig. 5). The ChRM components possess magnetite and hematite as the principal magnetic-bearer minerals that have high Curie temperatures $\left(580^{\circ} \mathrm{C}\right.$ for magnetite and $675^{\circ} \mathrm{C}$ for hematite) and high magnetic resistance during the thermal and $\mathrm{AF}$ 
Cung Thuong Chi, et al./Vietnam Journal of Earth Sciences 37 (2015)

demagnetizations (Fig. 4). These samples show excellent response in progressive alternating field and/or thermal demagnetization; the ChRM components are successfully isolated from the secondary components at about $350^{\circ} \mathrm{C}$ and $/$ or 20 $\mathrm{mT}$ and uniformly decayed toward the origin. There are some samples that have the ChRM components with very high magnetic resistances, which still exist at high alternative field - $100 \mathrm{mT}$ (Fig. 3).
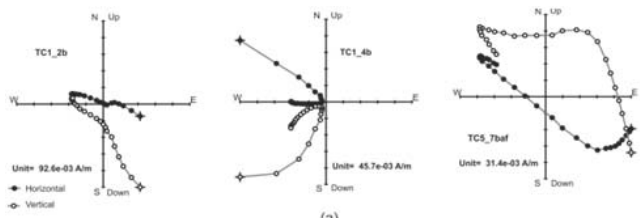

(a)
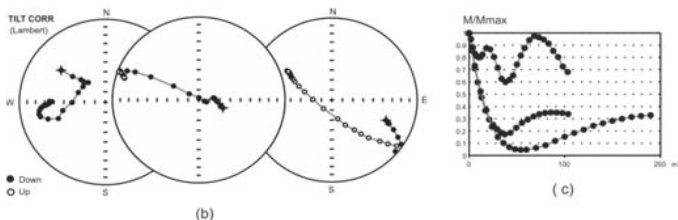

Fig. 3. Representative AF demagnetization plots of hard multiNRM components samples; (a) Zijderveld plots, (b) stereographic plots, (c) normalized magnetization plots.
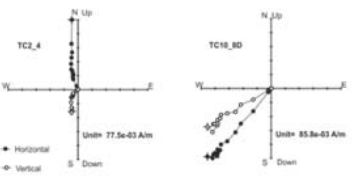

(a)

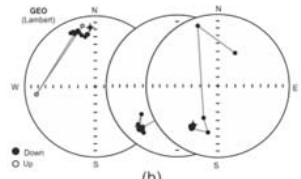

(b)
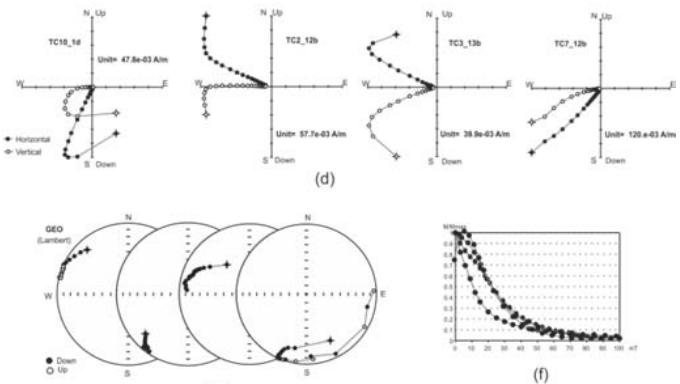

Fig. 4. Representative thermal and AF demagnetization plots of magnetite-bearer NRM samples; (a) \& (d): Zijderveld plots, (b) \& (e): stereographic plots, (c) \& (f): normalized magnetization plots

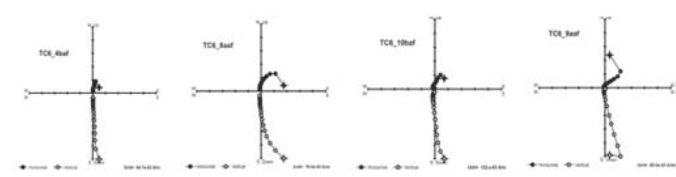

(a)

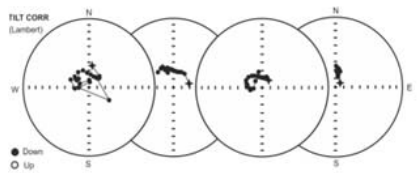

(b)

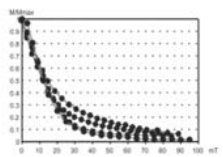

(c)

Fig. 5. Representative AF demagnetization plots of steepinclination samples that probably, their NRM were acquired during the reversal process of the Earth's geomagnetic field; (a) Zijderveld plots, (b) stereographic plots, (c) normalized magnetization plots.

\section{Paleomagnetic results}

The site-mean directions of ChRM components are plotted on the Lambert equal-area projection together with the mean paleomagnetic direction of Thuan Chau locality (Fig. 6) and their values are listed in table 1. Only four sites, which have a clear flow bedding orientation, are used to calculate the mean paleomagnetic direction for Thuan Chau locality. Their paleomagnetic directions are clearly different from the present geomagnetic direction of the study area as well as the paleomagnetic direction of younger rock formations in the northwestern Vietnam region (Cung et al., 2000; Takemoto et al., 2005), which reflect an ancient paleomagnetic direction. The formation mean direction of 4 sites yields the values $\mathrm{D}_{\mathrm{s}}=216.1^{\circ}$, $\mathrm{I}_{\mathrm{s}}=10.5^{\circ}, \alpha_{95}=8.9^{\circ}, \mathrm{k}=107.8$; corresponding to a virtual geomagnetic pole (VGP) located at $\lambda=$ $-5.6^{\circ} \mathrm{N}, \phi=46.8^{\circ} \mathrm{E}$ ( or $\lambda=45.6^{\circ} \mathrm{N}, \phi=226.8^{\circ} \mathrm{E}$ ). The mean paleomagnetic direction of Thuan Chau basalts is almost antipodal with that of Hoa Binh basalts $\left(\mathrm{D}=33.8^{\circ}, \mathrm{I}=-28.4^{\circ}\right)$ which indicates that the basaltic rocks from these localities had acquired their characteristic remanent magnetizations during a normal (Hoa Binh basalt) and reversed (Thuan Chau basalt) geomagnetic field. The reversal of the Earth's geomagnetic field during this time period has been also recorded in some samples from Thuan Chau locality with very deep inclination values (Fig. 5). 
Vietnam Journal of Earth Sciences 37 (2015) 289-298

Table 1. Paleomagnetic results of Late Permian basaltic rocks of Cam Thuy Formation

\begin{tabular}{|c|c|c|c|c|c|c|c|c|c|c|c|c|c|c|c|}
\hline \multirow[t]{2}{*}{ Site } & \multicolumn{2}{|c|}{ Location } & \multirow{2}{*}{\multicolumn{2}{|c|}{$-\frac{\mathrm{Az} / \mathrm{Dp} n / \mathrm{N}}{(\mathrm{o})}$}} & \multicolumn{6}{|c|}{ ChRM } & \multicolumn{2}{|c|}{ VGP } & \multirow{2}{*}{$\frac{\mathrm{dp}}{(\mathrm{o})}$} & \multirow{2}{*}{$\frac{\mathrm{dm}}{(\mathrm{o})}$} & \multirow{2}{*}{$\frac{\lambda \text { paleo }}{\left({ }^{\circ} \mathrm{N}\right)}$} \\
\hline & $\lambda\left({ }^{\circ} \mathrm{N}\right)$ & $\phi\left({ }^{\circ} \mathrm{E}\right)$ & & & $\mathrm{Dg}$ & $\mathrm{Ig}$ & Ds & Is & $\alpha 95$ & $\mathrm{k}$ & $\lambda\left({ }^{\circ} \mathrm{N}\right)$ & $\phi\left({ }^{\circ} \mathrm{E}\right)$ & & & \\
\hline TC1-2* & 21.379 & 103.779 & - & $\overline{8 / 11}$ & 308.5 & 9.7 & - & - & $\overline{11.0}$ & $\overline{26.26}$ & 37.5 & 3.1 & $\overline{5.6}$ & $\overline{11.1}$ & 4.9 \\
\hline TC03* & 21.380 & 103.779 & - & $12 / 13$ & 298.0 & 6.0 & - & - & 4.3 & 102.7 & 27.1 & 5.9 & 2.2 & 4.3 & 3.0 \\
\hline TC06* & 21.380 & 103.726 & - & $10 / 12$ & 9.4 & 46.1 & - & - & 4.3 & 127.15 & 79.5 & 156.6 & 3.5 & 5.5 & 27.5 \\
\hline $\mathrm{TC} 07$ & 21.380 & 103.726 & $188 / 30$ & $12 / 12$ & 227.6 & 36.2 & 219.7 & 11.6 & 2.5 & 312.78 & -42.0 & 44.3 & 1.3 & 2.5 & 5.8 \\
\hline TC08 & 21.380 & 103.726 & $188 / 30$ & $9 / 9$ & 226.9 & 36.6 & 219.0 & 11.8 & 2.1 & 589.54 & -42.9 & 45.0 & 1.1 & 2.2 & 5.9 \\
\hline ТC09 & 21.380 & 103.726 & $188 / 30$ & $2 / 3$ & 228.6 & 34.3 & 221.1 & 10.1 & 5.2 & 2328.9 & -41.8 & 42.4 & 2.6 & 5.2 & 5.1 \\
\hline TC10 & 21.380 & 103.726 & $188 / 30$ & $13 / 14$ & 208.6 & 36.9 & 204.5 & 8.4 & 5.7 & 52.96 & -54.8 & 57.9 & 2.9 & 5.8 & 4.2 \\
\hline Mean G & 21.380 & 103.726 & & $4 / 7$ & 223.0 & 36.3 & & & 8.9 & 108.31 & -30.8 & 55.5 & 6.0 & 10.3 & 20.2 \\
\hline Mean S & 21.380 & 103.726 & & $4 / 7$ & & & & & 8.9 & 107.84 & -45.6 & 46.8 & 4.6 & 9.0 & 5.3 \\
\hline Or: & & & & & & & & & & & 45.6 & 226.8 & 4.6 & 9.0 & -5.3 \\
\hline
\end{tabular}

Note: $\left(^{*}\right)$ - sites are excluded from the calculation of site mean; Az/Dp: Azimuth of dip/Dip; ChRM: characteristic remanent magnetization; VGP: Virtual geomagnetic pole; lpaleo: Paleolatitude of the site.

Table 2. Late Permian virtual geomagnetic poles from South China and Indochina

\begin{tabular}{|c|c|c|c|c|c|c|c|}
\hline \multirow{2}{*}{ Age } & \multicolumn{2}{|c|}{ Locality } & \multicolumn{2}{|c|}{ VGP coord } & \multirow{2}{*}{$\mathrm{A}_{95}$} & \multirow{2}{*}{ Rock type } & \multirow{2}{*}{ Reference } \\
\hline & $\lambda$ & $\phi$ & $\lambda$ & $\phi$ & & & \\
\hline \multicolumn{8}{|l|}{ South China Block: } \\
\hline $\mathrm{P} 2$ & 29.6 & 103.4 & 52.7 & 252.1 & 6.0 & $\begin{array}{l}\text { Basalt and red sandstone } \\
\text { (Emeishan, Sichuan) }\end{array}$ & McEnhinny et al. 1981 \\
\hline $\mathrm{P} 2$ & 29.6 & 103.4 & 49.7 & 252.0 & 2.8 & Emeishan basalt & Zhao and Coe, 1989 \\
\hline $\mathrm{P} 2$ & 29.6 & 103.4 & 54.1 & 241.8 & 19.0 & $\begin{array}{l}\text { Basalt and limestone } \\
\text { (Emeishan, Sichuan) }\end{array}$ & Chan et al. 1984 \\
\hline $\mathrm{P} 2$ & 29.6 & 103.5 & 38.5 & 231.6 & 4.9 & Emeishan basalt, Xihekou & Liu et al. 1985 \\
\hline $\mathrm{P} 2$ & 28.1 & 102.9 & 58.9 & 246.1 & 6.6 & Basalt, Zhaojue, Sichuan & Liu et al. 1985 \\
\hline $\mathrm{P} 2$ & 27.6 & 101.9 & 63.5 & 264.3 & 9.8 & Basalt, Yanguan, Sichuan & Liu et al. 1985 \\
\hline $\mathrm{P} 2$ & 28.3 & 103.0 & 54.3 & 251.2 & 20.0 & Basalt, Meigou, Sichuan & Zhou et al. 1986 \\
\hline $\mathrm{P} 2$ & 26.8 & 101.8 & 25.6 & 216.4 & 12.6 & Basalt, Miyi, Sichuan & Zhou et al. 1986 \\
\hline $\mathrm{P} 2$ & 26.7 & 102.9 & 53.5 & 241.8 & 10.1 & Basalt, Huidong, Sichuan & Huang et al., 1986 \\
\hline $\mathrm{P} 2$ & 26.1 & 103.1 & 52.5 & 226.0 & 25.0 & Basalt, Dongchuan, Yunnan & Huang et al., 1986 \\
\hline $\mathrm{P} 2$ & 25.9 & 100.6 & 24.7 & 204.3 & 24.8 & Basalt, Binhchuan, Yunnan & Huang et al., 1986 \\
\hline $\mathrm{P} 2$ & 26.4 & 105.7 & 29.3 & 235.3 & 13.4 & Basalt, Xiongjiachang, Guizhou & Lin, 1984 \\
\hline $\mathrm{P} 2$ & 25.6 & 103.0 & 50.0 & 241.0 & 6.1 & Basalt, Kunming, Yunnan & Fang \& Vander Voo, 1990 \\
\hline $\mathrm{P} 2$ & 29.6 & 103.5 & 38.5 & 231.6 & 4.9 & Emeishan basalt, Xihekou & Liu et al. 1985 \\
\hline $\mathrm{P} 2$ & 26.5 & 101.8 & 23.6 & 210.3 & 9.1 & & Zhou et al., 1988 \\
\hline $\mathrm{P} 2$ & 26.5 & 101.8 & 28.9 & 218.2 & 6.4 & & Zhou et al., 1988 \\
\hline $\mathrm{P} 2$ & 28.3 & 103.0 & 57.0 & 277.1 & 12.7 & & Zhou et al., 1988 \\
\hline $\mathrm{P} 2$ & 28.3 & 103.0 & 47.1 & 231.0 & 19.0 & & Zhou et al., 1988 \\
\hline $\mathrm{P} 2$ & 29.6 & 103.4 & 54.1 & 241.8 & 19.5 & & Lung et al., 1984 \\
\hline $\mathrm{P} 2$ & 29.6 & 103.4 & 51.2 & 232.5 & 2.9 & & Zhang 1984 \\
\hline $\mathrm{P} 2$ & 29.6 & 103.4 & 48.9 & 251.1 & 4.0 & & Zhao and Coe, 1987 \\
\hline $\mathrm{P} 2$ & 26.4 & 104.7 & 41.5 & 222.7 & 4.5 & Emeishan basalt & Huang and Opdyke, 1998 P2 \\
\hline Mean of 22 poles: & 47.4 & 235.5 & 6.7 & & & & \\
\hline \multicolumn{8}{|l|}{ Indochina Block: } \\
\hline $\mathrm{P} 2$ & 16.7 & 101.8 & 58.4 & 176.2 & 7.2 & $\begin{array}{l}\text { Limestone, Khorat Plateau, } \\
\text { Thailand Yang\& Bese, } 1993\end{array}$ & \\
\hline $\mathrm{P} 2$ & 21.5 & 103.7 & 45.6 & 226.8 & 8.9 & $\begin{array}{l}\text { Basalt, Thuan Chau, NW } \\
\text { Vietnam }\end{array}$ & This study \\
\hline $\mathrm{P} 2$ & 29.6 & 103.4 & 48.9 & 251.1 & 4.0 & & Zhao and Coe, 1987 \\
\hline $\mathrm{P} 2$ & 26.4 & 104.7 & 41.5 & 222.7 & 4.5 & Emeishan basalt & Huang and Opdyke, 1998 P2 \\
\hline
\end{tabular}


Cung Thuong Chi, et al./Vietnam Journal of Earth Sciences 37 (2015)
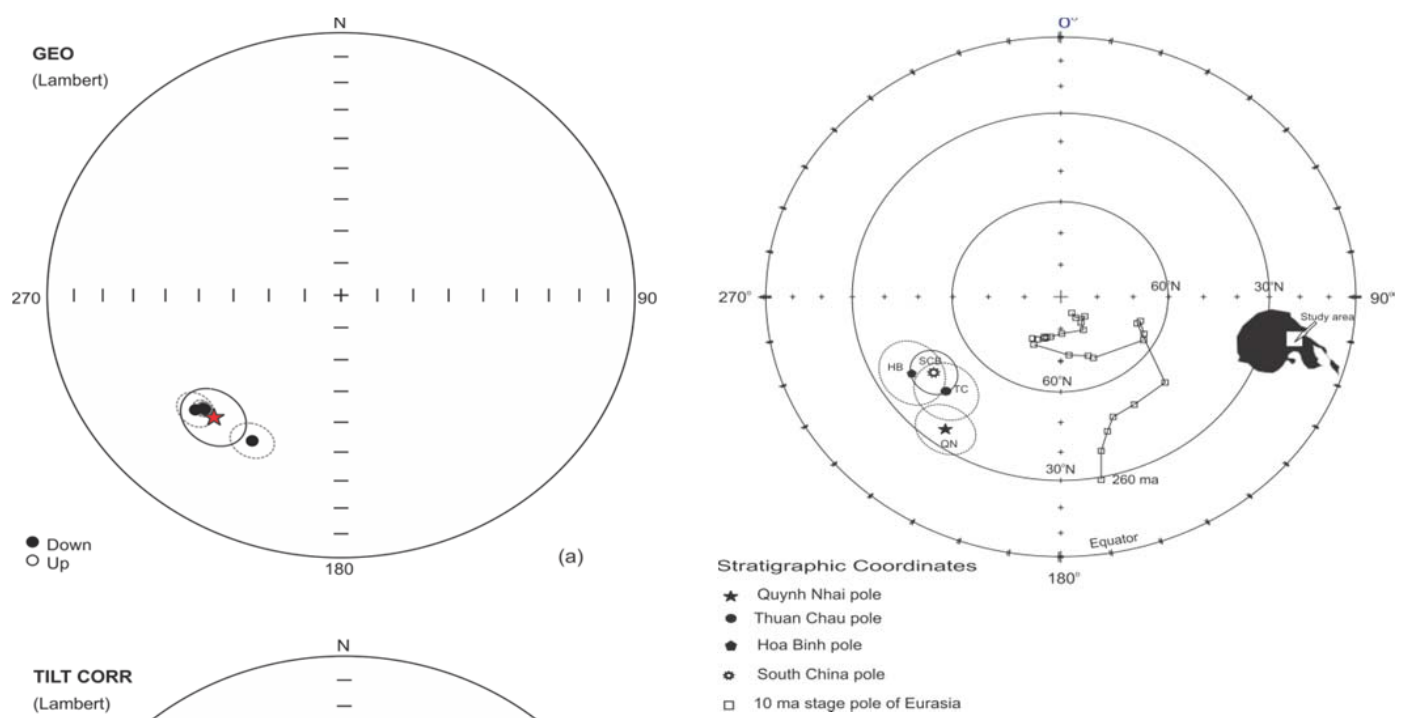

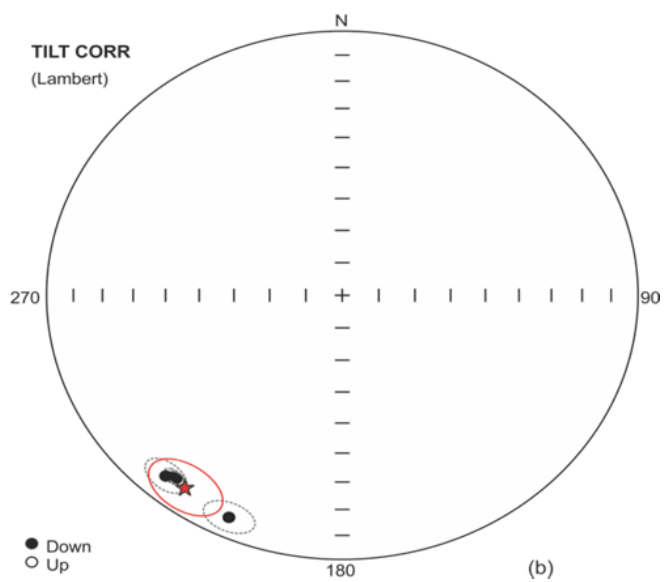

Fig. 6. Lambert equal-area diagram showing the site mean direction and the mean direction of 4 sites with the ellipse of $95 \%$ confidence. (a) in geographic coordinates; (b) in stratigraphic coordinates

The paleopole position of Thuan Chau basaltic rocks is basically indistinguishable from that of Late Permian-Early Triassic basaltic rocks from Hoa Binh locality $\left(\lambda=41.1^{\circ} \mathrm{N}, \phi=239.8^{\circ} \mathrm{E}\right)$ and from the paleopole of Permian Emeishan basalts in South China (Fig. 7). The similar paleopole positions of two distal basaltic rock formations from NW Vietnam and South China further corroborate the hypothesis of coeval time emplacement. The paleolatitude of the study area calculated from the formation mean direction is $\lambda_{\text {obs }}= \pm 5.3^{\circ} \mathrm{N}$ indicating that the Thuan Chau basaltic rock formation was emplaced on the Earth during Late Permian time near the equatorial region.
Fig. 7. Equal-area diagram showing the position of VGP pole of Thuan Chau locality relative to coeval paleopoles of Hoa Binh, Quynh Nhai areas and the South China Block, and the APWP of Eurasia

Using the mean paleopole of Upper Permian volcanic rock formations from South China Block (table 2), the expected paleomagnetic direction of Thuan Chau locality is computed and has the values: $D_{e x}=30.7^{\circ}, I_{e x}=-16.8^{\circ}, \lambda_{e x}=-8.6^{\circ} \mathrm{N}$.

\section{Discussion}

According to the paleogeographic reconstruction models, the northwestern Vietnam, in general, and the Thuan Chau locality, in particular, belongs to the South China Block but not to the ancient Indochina Block as described by Metcalfe, 2011, 2012 because the Song Ma Suture situates to the southwest of this region. The rotation and latitudinal translation of Thuan Chau locality relative to the South China Block are calculated and have the values as follow: $\mathrm{R}=5.4^{\circ} \pm 9.0^{\circ}, \mathrm{d}=$ $-3.3^{\circ} \pm 8.9^{\circ}$; which are statistically insignificant indicating that the Thuan Chau locality has been relatively stable with respect to the South China Block since the Late Permian. The stable position of Thuan Chau area with respect to the South China Block deduced from the paleomagnetic results of this study is consistent with that of Late Permian-Early Triassic basaltic formations from Hoa Binh and Quynh Nhai area (Cung et al., 2015 - in press) and also consistent with that of 
Vietnam Journal of Earth Sciences 37 (2015) 289-298

Cretaceous red-bed formations from NW Vietnam region reported by (Cung et al., 2000b; Takemoto et al., 2005).

The consistency of paleomagnetic information on relative tectonic displacement of northwestern Vietnam region obtained from different rock formations with different geological ages shows that this region has been close to if not a coherent part of the South China Block since the Late Permian. This result implies that insignificant cumulative displacement has occurred along the Ailao Shan/Red River fault system during the Cenozoic India-Eurasia collision.

\section{Conclusions}

The characteristic remanent magnetizations of basaltic rocks from Thuan Chau area have been acquired during a reversal of the Earth's geomagnetic field occurred in the Late Permian time and their paleomagnetic directions are almost antipodal with that of Hoa Binh basaltic rocks.

The Thuan Chau locality, in particular, and the northwestern Vietnam region, in general, has been a coherent part of the South China Block and situated near the Equator during the Late Permian.

The Ailao Shan/Red River fault system has played a minor role during the Cenozoic IndiaEurasia collision and there is insignificant cumulative displacement along this fault in terms of paleomagnetism.

If the Indochina Block had been indeed extruded southward during the India-Eurasia collision, this motion would be occurred along some other faults located to the south of the study area.

\section{Acknowledgements}

This research has been supported by a grant for the basic research project (No.105.042011.24) from National Foundation for Science and Technology Development (Nafosted) of Vietnam to Cung Thuong Chi. Part of Geissman's travel support and paleomagnetic measurements were provided by the University of Texas Stars Program.

\section{References}

Achache, J., and V. Courtillot, 1985: A preliminary Upper Triassic paleomagnetic pole for the Khorat Plateau
(Thailand): Consequences for the accretion of Indochina against Eurasia. Earth Planet. Sci. Lett., 73, 147-157.

Cai, J.-X., Zhang, K.J., 2009: A new model for the Indochina and South China collision during the Late Permian to the Middle Triassic. Tectonophysics 467, 35-43.

Chan, L.S., Wang, C.Y., and Wu, X.Y., 1984: Paleomagnetic results from some Permian-Triassic rocks from southwestern China. Geophys. Res. Lett., 11, 11, 1157-1160.

Chen, Y., and V. Courtillot, 1989: Widespread Cenozoic (?) remagnetization in Thailand and its implications for IndiaAsia collision. Earth Planet. Sci. Lett., 93, 113-122.

Cung Thuong Chi, 1996: Paleomagnetism of Mesozoic and Cenozoic rocks from Vietnam: Implications for the Tertiary tectonic history of Indochina and a test of the extrusion model. Ph.D. Dissertation, 228pp., Texas A\&M University, College Station, Texas, USA.

Cung Thuong Chi, Nguyen Quoc Cuong, Nguyen Trong Yem, 2000a: Preliminary paleomagnetic results of Late PermianEarly Triassic basalts from northwestern Vietnam and their tectonic implications. Journal of Geology, A/259, 7-8/2000, 1-8 (In Vietnamese).

Cung Thuong Chi, Nguyen Trong Yem, Nguyen Quoc Cuong, 2000b: Paleomagnetic study on Late Jurassic-Cretaceous extrusive and intrusive rocks from northwestern Vietnam. Journal of Geology, A/256, 1-2/2000, 1-8. (In Vietnamese).

Dercourt, J., Ricou, L.E., Vrielynck, B. (Eds.), 1993: Atlas Tethys Palaeoenvironmental Maps Gauthier-Villars, Paris 307pp., 14 maps, 1 plate.

Enkin, R.J., 1990: Formation et deformation de 1'Asie depuis la fin de l'ere primaire: les apports de l'etude paleomagnetique des formations secondaires de Chine du Sud. Ph.D. Thesis, 333 pp., Univ. de Paris 7.

Enkin, R.J., Yang, Z., Chen, Y., and Courtillot, V., 1992b: Paleomagnetic constraints on the geodynamic history of the major blocks of China from the Permian to the present. J. Geophys. Res., 97, B10, 13,953-13,989.

Fang, W. and Van der Voo, R., 1990: Paleomagnetism of the Late Permian Emeishan basalt, Yunnan, China. Eos Trans. AGU, 71, 488 .

Fisher, R.A., 1953: Dispersion on a sphere. Proc. Roy. Soc. London, Series A, 217, 295-305.

Gatinsky, Y.G., and C.S. Hutchinson, 1986: Cathaysia, Gondwanaland and the Palaeotethys in the evolution of 


\section{Cung Thuong Chi, et al./Vietnam Journal of Earth Sciences 37 (2015)}

continental Southeast Asia. Proceed. GeoSea V Congress, Geol. Soc. Malaysia Bull., 20.

Glotov, A.I., Polyakov, G.V., Hoa, T.T., Balykin, P.A., Akimtsev, V.A., Krivenko, A.P., Tolstykh, N.D., Phuong, N.T., Thanh, H.H., Hung, T.Q., Petrova, T.E., 2001: The Ban Phuc Ni-Cu-PGE deposit related to the Phanerozoic komatiite-basalt association in the Song Da rift, northwestern Vietnam. Can. Mineral. 39, 573-589.

Hanski, E., Walker, R.J., Huhma, H., Polyakov, G.V., Balykin, P.A., Tran, Trong Hoa, Ngo, Thi Phuong, 2004: Origin of the Permian-Triassic komatiites, northwestern Vietnam. Contributions to Mineralogy and Petrology 147, 453-469.

Heller, F., Lowrie, W., li, H. and Wang, J., 1988: Magnetostratigraphy of the Permo-Triassic boundary section at Shangsi (Guanggyuan, Sichuan, China). Earth Planet. Sci. Lett., 88, 348-356.

Huang, K., Opdyke, N., Kent, D., Xu, G., and Tang, R., 1986: Further paleomagnetic results from the Permian Emeishan basalts in SW China (in Chinese). Kexue Tongbao, 31, 1192-1201.

Huang, K., Opdyke, N.D., Kent, D.V., Xu, Guizhong, Tang, Ruolong, 1986: New paleomagnetic results of Permian Emeishan basalts. Chinese Science Bulletin 2, 133-137 (in Chinese).

Huang, K., Opdyke, N.D., 1998: Magnetostratigraphic investigations on an Emeishan basalt section in western Guizhou province, China. Earth and Planetary Science Letters 163, 1-14.

Hutchinson, C.S., 1989: The palaeo-Tethyan realm and Indosinian orogenic system of Southeast Asia. In: Sengor, A.M.C. (Ed.). Tectonic Evolution of the Tethyan Region, 585-643, Academic San Diego, California, 1989b.

Kirschvink, J.L., 1980: The least-square line and plane and the analysis of paleomagnetic data. Geophys. J. R. Astron. Soc. London, 62, 699-718.

Lacassin, R., Leloup, P.H., Trinh, P.T., Tapponnier, P., 1998: Unconformity of red sandstones in north Vietnam: field evidence for Indosinian orogeny in northern Indochina? Terra Nova 10, 106-111.

Lepvrier, C., H. Maluski, Vu Van Tich, A. Leyreloup, Phan Truong Thi, Nguyen Van Vuong, 2004: The Early Triassic Indosinian orogeny in Vietnam (Truong Son Belt and Kontum Massif); implications for the geodynamic evolution of Indochina. Tectonophysics 393, 87- 118.
Lepvrier, C., Nguyen Van Vuong, Henri Maluski, Phan Truong Thi, Tich Van $\mathrm{Vu}, 2008$ : Indosinian tectonics in Vietnam. C. R. Geoscience 340, 94-111.

Li, Z.X., Powell, C.McA., 2001: An outline of the palaeogeographic evolution of the Australian region since the beginning of the Neoproterozoic. Earth Science Reviews 53, 237-277.

Li, Z.X., Zhang, I., Powell, C.McA., Trench, A., 1993: Palaeozoic global reconstructions, In: Long, J.A. (Ed.). Palaeozoic Vertebrate Biostratigraphy and Biogeography. Belhaven Press, London, pp. 25-53.

Lin, J.L., 1984: The apparent polar wonder paths for the North and South China blocks. Ph.D. Thesis, 248 pp. Univ. of California, Santa Barbara.

Liu, C., Zhu, R. and Jing, Z., 1985: Paleomagnetic study of Late Permian Emeishan basalts from Panxi and its neighbouring areas (in Chinese). In: Contributions to Panxi rift, China, Vol. 2, edited by Y. Zhang, pp. 194-200, Geological Publishing House, Beijing.

Lung, S.C.,Wang, C.Y.,Wu, X.Y., 1984: Paleomagnetic results from some Permian-Triassic rocks from southwestern China. Geophysical Research Letters 11 (11), 1157-1160.

McElhinny, M.W., 1981. Fragmentation of Asia in the Permian. Nature 293, 212-216.

Metcalfe, I., 1988: Origin and assembly of Southeast Asia continental terranes, Gondwana and Tethys, In: AudleyCharles, M.G., Hallam, A. (Eds.). Geological Society of London Special Publication 37, 101-118.

Metcalfe, I., 1991: Late Palaeozoic and Mesozoic palaeogeography of Southeast Asia. Palaeogeography, Palaeoclimatology, Palaeoecology 87, 211-221.

Metcalfe, I., 1996: Pre-Cretaceous evolution of SE Asian terranes. In: Hall, R., Blundell, D. (Eds.). Tectonic Evolution of Southeast Asia. Geological Society of London Special Publication 106, 97-122.

Metcalfe, I., 1998: Palaeozoic and Mesozoic geological evolution of the SE Asian region, multidisciplinary constraints and implications for biogeography. In: Hall, R., Holloway, J.D. (Eds.). Biogeography and Geological Evolution of SE Asia. Backhuys Publishers, Amsterdam, pp. 25-41.

Metcalfe, I., 2002: Permian tectonic framework and palaeogeography of SE Asia. Journal of Asian Earth Sciences 20 (2002) 551- 566. 
Vietnam Journal of Earth Sciences 37 (2015) 289-298

Metcalfe, I., 2011: Tectonic framework and Phanerozoic evolution of Sundaland. Gondwana Research 19, 3-21.

Metcalfe, I., 2012: Changhsingian (Late Permian) conodonts from Son La, northwest Vietnam and their stratigraphic and tectonic implications. Journal of Asian Earth Sciences 50 (2012) 141-149.

Phan Cu Tien, 1977: Late Permian -Early Triassic sediments from northwestern Vietnam. In: The geological problems of NW Vietnam region, Science and Technique Publisher House, Hanoi, pp.109-151 (In Vietnamese).

Polyakov, G.V., Tran Trong Hoa, Akimtsev, V.A., Balykin, P.A., Ngo Thi Phuong, Hoang Huu Thanh, Tran Quoc Hung, Bui An Nien, Tolstykh, N.D., Glotov, A.I., Petrova, T.E., Vu Van Van, 1999: Ore and geochemical specialization of Permo-Triassic ultramafic-mafic complexes in North Vietnam. Geologiya i Geofizika (Russian Geology and Geophysics) 40 (10), 1474-1487 (1453-1467).

Sengor, A.M.C., 1979: Mid-Mesozoic closure of PermoTriassic Tethys and its implications. Nature 279, 590-593.

Sengor, A.M.C., 1984: The Cimmeride orogenic system and the tectonics of Eurasia. Geological Society of America Special Paper 195, 82.

Sengor, A.M.C., 1987: Tectonic subdivisions and evolution of Asia. Bulletin of the Technical University of Istanbul 40, $355-435$.

Sengor, A.M.C., 1989: The Tethyside Orogenic System, an introduction, In: Sengor, A.M.C. (Ed.). Tectonic Evolution of the Tethyan Region. Kluwer, Dordrecht, pp. 1-22.

Scotese, C.R., McKerrow, W.S., 1990: Revised world maps and introduction. In: McKerrow, W.S., Scotese, C.R. (Eds). Palaeozoic Palaeogeography and Biogeography. Geological Society Memoir 12, 1-21.

Scotese, C.R., Golonka, J., 1992: Paleogeographic Atlas. Paleomap Progress Report 20-0692. Department of Geology, University of Texas at Arlington, 34pp.

Scotese, C.R., Langford, R.P., 1995: Pangea and the paleogeography of the Permian. In: Scholle, P.A., Peryt, T.M., Ulmer-Scholle, D.S. (Eds.). The Permian of northern Pangea. Paleogeography, Paleoclimate and Stratigraphy, Vol. 1, Springer, Berlin, pp. 3-19.

Sone, M., Metcalfe, I., 2008: Parallel Tethyan Sutures in mainland SE Asia: new insights for Palaeo-Tethys closure. Compte Rendus Geoscience 340, 166-179.
Steiner, M., Ogg, J., Zhang, Z. and Sun, S., 1989: The Late Permian - Early Triassic magnetic polarity time scale and plate motion of South China. J. Geophys Res., 94, 7343-7363.

Takemoto, K., Halim, N., Otofuji, Y., Tran Van Tri, Le Van De, Hada, S., 2005: New paleomagnetic constraints on the extrusion of Indochina: Late Cretaceous results from the Song Da terrane, northern Vietnam. Earth. Planet. Sci. Lett., 229, 273-285.

Tran Trong Hoa, 1996: Magmatic activities of Northwestern Truong Son belt in Mesozoic-Cenozoic. Material substances, forming conditions and mineral resource potential // J. Sci Earth. 18 (3), 218-227.

Tran Trong Hoa, 2001: Division and Comparison of PermianTriassic basaltoid complex of the Song Da zone. Journal of Geology A/265, 12-19, Hanoi, Vietnam (In Vietnamese).

Van Der Voo, R., Fang, W., Wang, Z., Suk, D., Peacor, R., Liang, Q., 1993: Paleomagnetism and electron microscopy of the Emeishan basalts, Yunnan, China. Tectonophysics 221, 367-379.

Yang, Z., Besse, J., 1993: Paleomagnetic study of Permian and Mesozoic sedimentary rocks from northern Thailand supports the extrusion model for Indochina. Earth Planet. Sci. Lett., 117, 525-552.

Zhang, K.J., Cai, J.-X., 2009: NE-SW-trending Hepu-Hetai dextral shear zone in southern China: penetration of the Yunkai Promontory of South China into Indochina. Journal of Structural Geology 31, 737-748.

Zhang, K.J., Cai, J.-X., Zhu, J.-X., 2006: North China and South China collision: insights from analogue modeling. Journal of Geodynamics 42, 38-51.

Zhang, Z.K., 1984: Sino-Korea and Yangze blocks were a part of Pacific paleocontinent in the Late Paleozoic. Bulletin of Chinese Academy of Geological Sciences 9, 45-54 (in Chinese).

Zhao, X.X., Coe, R.S., 1987: Palaeomagnetic constraints on the collision and rotation of North and South China. Nature $327,141-144$.

Zhou, M.F., Arndt, N.T., Malpas, J., Wang, C.Y., Kennedy, A.K., 2008. Two magma series and associated ore deposit types in the Permian Emeishan large igneous province, SW China. Lithos 103, 352-368. 


\section{Cung Thuong Chi, et al./Vietnam Journal of Earth Sciences 37 (2015)}

Zhou, Y., Lu, L., and Zheng, B., 1986: Paleomagnetic polarity of the Permian Emeishan basalt in Sichuan (in Chinese). Geol. Rev., 32, 465-469.

Zhou,Y.X., Lu, L.Z., Zhang, B.M., 1988: Preliminary paleomagnetic research for Panxi region. Collected Works for Panxi Rift No.3. Beijing Geological Publishing House, pp. 212-230 (in Chinese with English abstract).

Zhuang, Z.H., Jiang, X.X., Pan, Z.X., 1989: Paleomagnetism of the formation and development of Central Sichuan palaeoupwarp. A Research Report, pp. 1-87 (in Chinese).

Ziegler, A.M., Hulver, M.L., Rowley, D.B., 1997: Permian World Topography and Climate, In: Martinin, I.P. (Ed.).
Late Glacial and Postglacial Environmental Changes. Oxford University Press, New York, pp.111-146.

Ziegler, A.M., Gibbs, M.T., Hulver, M.L., 1998: A mini-atlas of oceanic water masses in the Permian Period. Proceedings Royal Society of Victoria 110, 323-343.

Zijderveld, J.D.A., 1967: A.C. demagnetization of rocks: Analysis of results, In: Methods in paleomagnetism, edited by D.W. Collinson, K.M. Creer, and S.K. Runcon, 254-286, Elsevier, New York.

Zonenshain, L.P., Kuzmin, M.I., Kononov, M.V., 1985: Absolute reconstructions of the Palaeozoic oceans. Earth and Planetary Science Letters 74, 103-116. 